\title{
First Report of Passalora concors (Casp.) Causing Cercospora Leaf Blotch in the Andean Region of Cochabamba, Bolivia
}

\section{Morante MC*}

Departamento de Fitotecnia y Producción Vegetal, Facultad de Ciencias Agrícolas, Pecuarias, Forestales y Veterinarias "Dr. Martin Cárdenas", Universidad Mayor de San Simón. Cochabamba, Bolivia

\begin{abstract}
Cercospora leaf blotch-infected plants of the native potato variety Waych'a Paceña (Solanum tuberosum subsp. andigena), collected between November and December of 2011 in the Piucilla-Morochata area of the Andean region of Cochabamba, Bolivia, were examined to determine the causal agent of the disease. The infecting pathogen was identified as Passalora concors (Syn. Cercospora concors (Casp.). This is the first report of this fungus causing Cercospora leaf blotch in the Andean highlands of Bolivia.
\end{abstract}

Keywords: First report; Potato diversity; Disease intensity; Native potato

The potato (Solanum tuberosum L.) has traditionally been grown in the highlands of Bolivia. The diversity of native potatoes in this region is high. Seed potato production is an important activity in certain highland areas of the Dept. of Cochabamba, such as Morochata, Independencia, Lope Mendoza and their areas of influence [1]. The cold temperatures and high humidity of these areas are favourable to the appearance of late potato blight caused by Phythophora infestans Mont. De Bary, a disease known by local farmers as T'octu. Cercospora leaf blotch also appears in the area, caused by Alternaria solani, Cercospora solanicola, Cercospora solani, Septoria lycopersici and Phoma andina [2].

Cercospora leaf blotch caused by Passalora concors (Casp.) Sacc
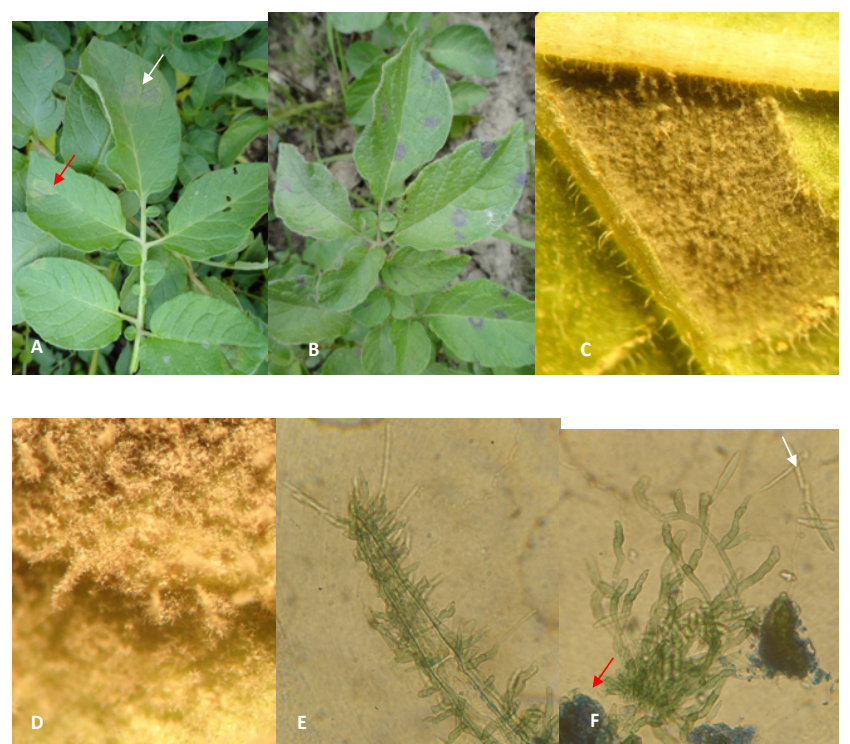

Figure 1: Symptoms and causal agent of Cercospora leaf blotch on Waych'aPaceña potatoes (Solanumtuberosumsubspandinega).

A: yellowing area (red arrow) and soft yellow halo (white arrow);

$B$ : advanced leaf blotches become black;

C: on the underside of the leaf, a grey colour appears, similar in appearance to downy mildew;

$\mathrm{D}$ : close up of the grey layer on the underside of a leaf; the hairs show hyphae on them;

$\mathrm{E}$ : a hair covered with hyphae of $P$. concors; F: conidiophore and conidia of $P$. concors.
(Syn. Cercospora concors [Casp.] Sacc.) has been reported in areas of cool temperate climate in Europe, the former Soviet Union, North America, in some restricted areas of Africa and Asia [3] and more recently in China [4]. This disease is considered to be of minor importance, and may occur simultaneously with other potato leaf diseases such as late blight (caused by $P$. infestans Mont. De Bary) and early blight (caused by Alternaria solani Sorauer) [3]. Until now it has never been reported as causing the disease in the Bolivian Andes.

During November and December of 2011, trips were made to examine the leaf diseases affecting Waych'a Paceña (Solanum tuberosum subsp. andigena) seed potato plants in the Piucilla-Morochata area (centering on $17^{\circ} 13^{\prime} 34^{\prime \prime} \mathrm{S}, 66^{\circ} 30^{\prime} 17^{\prime \prime} \mathrm{W}$; altitude $3320 \mathrm{~m}$ ). The leaves of plants showing signs of disease were collected, and the fungi they harboured isolated on dextrose agar plates. Leaf spots were observed under a stereomicroscope and the reproductive structures of the associated fungi mounted on slides in lactophenol solution for further inspection.

Symptoms of Cercospora leaf blotch were seen on all the leaves collected. The severity of infection ranged from $10-20 \%$, as determined using Image Analysis software. The disease preferably affected the lower to middle leaves, starting as yellowish-green, circular to irregular blotches on the upper adaxial surface (Figure 1A). Gradually the centres of these blotches become grey to black with a soft yellow halo (Figure 1B). As the blotches enlarged they all become black (Figure 1B). A fluffy grey layer of conidiophores and conidia eventually forms on the abaxial side of the leaves, (Figures $1 \mathrm{C}$ and 1D). Hyphae were observed growing over the leaf hairs (Figures $1 \mathrm{D}$ and $1 \mathrm{E}$ ). The conidiophores occurred in dense fascicles above the stomata; these were irregular in width, greyish, and highly branched (Figure 1F). The conidia were variable in size, catenate and slightly curved, obclavate, pale olivaceous,

*Corresponding author: Morante MC, Departamento de Fitotecnia y Producción Vegetal, Facultad de Ciencias Agrícolas, Pecuarias, Forestales y Veterinarias "Dr. Martin Cárdenas", Universidad Mayor de San Simón. Cochabamba, Bolivia, Tel: +25191476 0384; E-mail: cocamorante.mario@gmail.com

Received: March 02, 2014; Accepted March 29, 2014; Published April 07, 2014

Citation: Morante MC (2014) First Report of Passalora concors (Casp.) Causing Cercospora Leaf Blotch in the Andean Region of Cochabamba, Bolivia. J Plant Pathol Microb 5: 221. doi:10.4172/2157-7471.1000221

Copyright: (c) 2014 Morante MC. This is an open-access article distributed under the terms of the Creative Commons Attribution License, which permits unrestricted use, distribution, and reproduction in any medium, provided the original author and source are credited. 
Citation: Morante MC (2014) First Report of Passalora concors (Casp.) Causing Cercospora Leaf Blotch in the Andean Region of Cochabamba, Bolivia. J Plant Pathol Microb 5: 221. doi:10.4172/2157-7471.1000221

Page 2 of 2

smooth, nonseptate, and 12-16 $\mu$ in length $\times 3-6 \mu$ in width. (Figure 1F).

On the basis of these morphological features, and using the keys of Ellis [5] and Crous and Braun [6], the causal agent was identified as Passalora concors, the synonym of Cercospora concors (Casp.) (Crous). This is the first report of this fungus causing Cercospora leaf blotch in the Andean highlands of Bolivia.

\section{Acknowledgement}

The author is grateful to Javier Burgos Villegas, principal investigator at the Centro de investigacion en Sistemas y Teledetecion (CISTEL), Facultad de Ciencias Agricolas, Pecurias, Forestales y Veterianarias "Dr. Martin Cardenas", Universidad Mayor de San Simon, for valuable comments and suggestions, and for the collection samples in the field. Thanks are also owed the farmers of the Piucilla-Morochata area for the help received during this work. The author also thanks Adrian Burton for editorial assistance.

\section{References}

1. Coca Morante M (2010) Las papas en Bolivia: una aproximación a la realidad del mejoramiento del cultivo de la papa en Bolivia. 1era Edición. Cochabamba, Bolivia: $40-43$

2. Navia O, Plata G, Gandarillas A (2009) Manchas foliares fungosas: $42-45$.

3. Turkensteen (1981) Compendium of Potato Diseases: Cercospora leaf blotches or Cercospora leaf spots. American Phytopathological Society: 65.

4. Tian SM, Ma P, Liu DQ, Zou MQ (2008) First Report of Cercosporaconcors Causing Cercospora Leaf Blotch of Potato in Inner Mongolia, North China. Plant Disease Vol 92, Number 4, pag 654.

5. Crous PW, Braun U (2003) Mycosphaerella and its anamorphs: 1. Names published in Cercospora and Passalora. CBS Biodiversity Series 1: 1-571.

6. Gandarillas A, Ortuño NY (2009) Compendio de enfermedades, insectos nematodos y factores abióticos que afectan al cultivo de la papa en Bolivia. Fundación PROINPA. Cochabamba, Bolivia: 181. 